\title{
Degrowth, anthropology, and activist research: the ontological politics of science
}

\author{
Ulrich Demmer $^{1}$ \\ Agata Hummel \\ Ludwig Maximilians-Universität Munich, Germany \\ University of Adam Mickiewicz, Poznań, Poland
}

\begin{abstract}
This article argues that scientific practice of all kinds does not simply represent but actively constructs social and cultural realities: it is involved in an "ontological politics." It reflects on activist research and addresses the question of how science, and especially anthropology, can contribute to bringing degrowth alternatives into being. We suggest that to overcome growth society and build a new imaginary, we first need to denaturalize and decenter basic concepts of modern ontology. We then show how and why activist researchers in new social movements such as degrowth are involved in bringing about new concepts, imaginaries, and practices. Drawing on our experiences as activist researchers, we propose some basic strategies and tools for activist research, including deconstruction, and the creation and/or use of new concepts, such as translation and weaving.
\end{abstract}

Key words: ontological politics, activist research, degrowth, alternatives to modernity

\section{Résumé}

Cet article soutient que les pratiques scientifiques de tous les genres ne servent pas seulement à représenter ou à établir des constructions de réalités sociales et culturelles: la science est impliquée dans « des politiques ontologiques ». Ce texte poursuit des réflexions existantes sur des investigations activistes, et aborde la question de comment la science, et notamment l'anthropologie, peut contribuer d'une meilleure manière à rendre réels les alternatives de décroissance. Nous suggérons que pour surmonter la société de croissance et construire un nouvel imaginaire, nous devons d'abord déconstruire, dénaturaliser, et décentraliser les concepts fondamentaux de l'ontologie moderne. Par la suite, nous allons indiquer comment et pourquoi les chercheurs activistes dans les nouveaux mouvements sociaux tels que la décroissance s'intéressent à d'introduire de nouveaux imaginaires et de nouvelles pratiques par le biais de production de connaissances et de pratiques. En nous basant sur nos expériences comme chercheurs activistes, nous proposons quelques stratégies et méthodes telles que la déconstruction, la création et/ou utilisation de nouveaux concepts, la traduction, et le tressage.

Mots-clés: politiques ontologiques, recherche activiste, décroissance, alternatives à la modernité

\footnotetext{
${ }^{1}$ Equal authorship. Dr. Ulrich Demmer, Ludwig-Maximilians-Universität Munich, Department of Social and Cultural Anthropology, Germany and Transition Town Heidelberg, Co-munity.net./Degrowth. Email: ulrich.demmer "at" tonline.de. Dr. Agata Hummel, Department of Ethnology and Cultural Anthropology, University of Adam Mickiewicz in Poznań, Poland and Co-munity.net./Degrowth. Email: agahum "at" amu.edu.pl. Ulrich wants to thank the members of Transition Town Heidelberg for their friendship and cooperation. His activist research was not funded by any agency. Thanks to all the professors who commented on the article at the Department of Ethnology and Cultural Anthropology seminar at the University of Adam Mickiewicz. On some issues in section 2 we owe inspiration to Hadas Reshef, a student in the same Department. This is the eleventh article in Lisa L. Gezon and Susan Paulson (eds.) 2017. "Degrowth, culture and power," Special Section of the Journal of Political Ecology, 24: 425-666.
} 


\section{Resumen}

Este artículo argumenta que la práctica científica de todo tipo no solo representa pero activamente construye realidades sociales y culturales: está involucrada en "políticas ontológicas." Continúa la reflexión existente acerca de la investigación activista y aporta reflexiones de cómo la ciencia, sobre todo la antropología, puede contribuir de la mejor forma a hacer reales las alternativas de decrecimiento. Sugerimos que para superar la sociedad de crecimiento y construir un nuevo imaginario primero tenemos que desconstruir, desnaturalizar y descentralizar los conceptos básicos de la ontología moderna. Indicamos cómo y por qué los investigadores activistas en nuevos movimientos sociales como el decrecimiento están involucrados en producir nuevos imaginarios y prácticas a través de la construcción de conocimientos y prácticas. Finalmente, basándonos en nuestras experiencias como investigadores activistas, proponemos algunas estrategias básicas que podría conllevar un conjunto de herramientas para la investigación activista, tales como desconstrucción, creación y/o uso de nuevos conceptos, traducción y trenzado.

Palabras clave: políticas ontológicas, investigación activista, decrecimiento, alternativas a la modernidad

\section{Introduction}

If methods are not innocent then they are also political. They help to make realities. But the question is: which realities? Which do we want to help to make more real, and which less real? How do we want to interfere (because interfere we will, one way or another)? (Law and Urry 2004: 404)

We (Agata and Ulrich) are both engaged in socio-ecological movements including Degrowth, Transition Towns, and Community Supported Agriculture. Like other researchers we seek to contribute as researchers and activists to the realization of the ways of life that these frameworks support. What we experience in that process is a blurring of activist and scientist roles. We share this experience with other scientists who are politically engaging degrowth (e.g. Cattaneo 2006; Demaria et al. 2013; Martínez-Alier et al. 2014).

What this merging of science and activism means for our theories and our methods calls for further elaboration. In this article, therefore, we urge more explicit acknowledgement that, just like activist practices, science is also actively involved in the making of what we study in what has been called the ontological politics, or the performativity, of science (Law and Urry 2004). In fact, we argue, our engagement as scientists and the knowledge production it entails is important for our aim of making alternatives to modernity possible.

In the first part of this article, we argue that activist research on degrowth can be enriched by paying close attention to its socio-cultural dimensions. Anthropological approaches stress ethical-practical emic perspectives and their complexity. ${ }^{2}$ There have been attempts to apply engaged ethnography to degrowth (e.g. Cattaneo 2006; Demaria et al. 2013; Escobar 2009, 2012; Martínez-Alier et al. 2014), but they need further development. We offer a tool-kit for anthropologically informed activist research, bringing together theoretical/epistemological reflections with concrete examples of social practices thwarting and enabling alternatives (Slocum and Cadieux 2015: 29). In particular, we join a "third generation" of political ecologists and their increasing "scholarly engagement with activism and socio-ecological movements" where researchers become "scholar-practitioners," practicing "an applied, practical political ecology" (cf. Rocheleau 2007: 721-723). This implies "the explicit recognition of multiple actors and identities and of a rising cultural politics within many movements" (p. 721) in anthropologically informed empirical study of such movements and alternatives to sustainable development (p. 720). As Rocheleau puts it, such a twofold scholarly

\footnotetext{
${ }^{2}$ Insider approach to the studied culture or group of people. An approach in which we try to understand studied phenomena using categories proper to the studied subjects.
} 
engagement "is one way to harness practical political ecology, and to demonstrate that many other worlds are possible and practical" (p. 723).

In a second part, we ground our call for activist research in the ontological politics and performative character of all science. In part three, we focus on specific characteristics and practices of new social movements that not only involve a blurring of activism and science but also lead to a post-normal science paradigm, where "the facts are uncertain, values are in dispute, stakes are high, and decision urgent." This requires an "extended peer-community, consisting not only of scientists but also other legitimate participants" involved in the debate (Funtowicz and Ravetz 1993: 744; D'Alisa and Kallis 2015: 185). In the fourth part, drawing on our personal experiences in and with socio-ecological movements, we outline important activist research strategies.

\section{Engaged anthropology and the ontological politics of science}

We are engaged in what has been called the ontological politics of science. This includes the awareness that people everywhere are involved in the politics of making realities through practices of knowledge production, and that scientific knowledge is just one among many other forms of knowledge (religious, spiritual, everyday, etc.). The ontological politics of science underscores the awareness that we, as scientists, choose to consciously (co-)construct what we are interested in through non-hierarchical engagements in and with the objects of study. This contrasts with a modern ontological position that assumes the existence of one reality that may have different interpretations, among which the rational one has primacy over others (Blaser 2013).

The ontological politics of science has three major dimensions. First, social scientists (like any other sciences) are not neutral in relation to the phenomena we study. Instead, as researchers, we take an evaluative subject position in relation to our objects of study and, in doing research, we actively bring about the reality we are concerned with. Law and Urry have called this the performative function of science and knowledge. The social sciences, for instance "have always been embedded in, produced by, and productive of the social" (2004: 392).

Second, performing or constructing reality through science involves intersubjective interactions that are co-constructed both relationally and interactively (Law and Urry 2004). For anthropologists as activists, this may mean participating in meetings; in the economics of production, sharing, or distribution; in protests, squatting, theory building, in degrowth conferences, summer schools, and so on. Researchers and science "reflect upon, and enact the social in a wide range of locations" (Law and Urry 2004: 392).

Third, ontological politics and performativity of knowledges are always motivated and driven by ethical concerns, evaluations, and goals. If, for example, researchers are interested in optimizing nuclear power plants, they are not only driven by technical questions, but they may also adhere to the idea of a good life that rests on or comes about with the advancement of high technology. If, in contrast, our research on degrowth is concerned with issues such as voluntary simplicity, the commons, gifting, sharing, dépense, etc. (D'Alisa et al. 2015), this interest is also motivated by concerns of, and the care for, a good life. In sum, then, because sciences and methods help to establish realities, and because our work involves ethical assumptions and motivations, we must ask: "which realities? Which do we want to help to make more real, and which less real? How do we want to interfere (because interfere we will, one way or another)?" (Law and Urry 2004: 404).

This last question raises the issue of methodology and provokes a consideration of which methods of engaged research are appropriate for achieving alternatives to aspects of modernity. ${ }^{3}$ We propose three major

\footnotetext{
${ }^{3}$ In our understanding of alternatives to modernity we follow Escobar's definition. Modernity, he argues, must be understood in "reference to the coloniality of power that accompanied it and that entailed the marginalization of the cultures and knowledge of subaltern groups." Alternatives to modernity are radical and visionary political projects of "redefining and reconstructing local and regional worlds from the perspective of practices of cultural, economic, and
} 
tools of activist, collaborative inquiry: deconstruction, weaving, and translation. In our fieldwork, all three appeared as crucial instruments of activist research.

Translation refers to the activity of putting into new codes or words certain lesser-known concepts that emerge as vital for new social movements and transformative actors. In Ulrich's experiences with the urban Transition Town group, for example, both the group and Ulrich himself searched for a new selfunderstanding and found it in the term 'rhizome,' which is able to articulate the highly flexible and heterogeneous membership of urban groups and their creative ways of producing knowledges and relationships. ${ }^{4}$ Similarly, the social organization of the community-supported agriculture and degrowth networks Agata works with is also usefully understood as a rhizome. The task of searching for and creating new concepts is not confined to science. Many movements (Anti-G8, Larzac; Transition Town, Zapatismo, Buen Vivir and others) are engaged in making innovative theories and analyses.

'Weaving,' on the other hand, denotes the various processes of constructing networks of people (including researchers) and knowledges. In our experience, the rhizomatic degrowth network is a creative space of knowledge construction exactly because actors/activists (including researchers) can connect with one another and contribute their different knowledges across regions or countries (countryside and city in Poland, Germany, Spain etc.) through a variety of devices and platforms (e.g. internet, reading groups, work groups, etc.).

Both tools (translation, weaving) depend on an additional, third instrument of activist research, which is 'deconstruction' or 'decentering.' As our research makes clear, to arrive at new concepts and understandings (such as the rhizome) requires decentering and overcoming the common sense knowledge of actors. The degrowth network we are both engaged in, for example, is searching for new concepts that go beyond the dualist framework expressed in the distinction of individual choice, maximization of profit, utilitarianism, on the one hand, and 'gift', altruism or affluence on the other. These dualisms derive from a modern capitalist ontology (cf. Escobar 2012) that is not compatible with the goals of degrowth. We need new concepts to describe, for instance, the alternative economics of degrowth projects, such as the one Agata is working with in Catalonia, or new concepts like the 'rhizome.' However, despite its being a precondition for activist research, the decentering of the modern ontology is rarely described. In this article, therefore, we make appropriate space for the description of this tool (in section four).

\section{Activism, knowledge construction and the practices of socio-ecological movements}

What is most characteristic of social movements is the "imperative of action" (Williams 2008: 72), which involves protesting and "direct action" (Graeber 2009) as well as long-term endeavors of building concrete alternatives such as agro-ecological farming (Luetcheford and Pratt 2014) and rurban socioecological co-housing (Cattaneo et al. 2015). Many movements transcend the binary division between action and thought. One of Agata's neorural research collaborators criticized activism for being only action without thinking. He then insisted that revolutionary action must be accompanied by the development of critical and constructive thought. As Osterweil (2013) points out, new social movements also involve theoretical practices (Osterweil 2013; Cf. also Escobar 2012; and Santos 2007). During the course of action, "analysis, deconstruction, and political readings are rendered public, then discussed, debated, refuted, embraced" (Osterweil 2013: 606). ${ }^{5}$ Public action also serves as a practice for instigating theoretical reflexivity. Activists

ecological difference, following a network logic and in contexts of power" (Escobar 2008: 162-163).

${ }^{4}$ For Deleuze and Guattari (1987) the rhizome is (among other things) a social organism (e.g. a human group) always in the making through ongoing (practical, material and discursive) connective, disconnective, creative and ethical (good or bad) interactions between heterogenous individuals: it is a multiplicity. A rhizome is also political in an ethical sense because it is only "good" if actors create and maintain non-hierarchical conncetions against ever-present desires to establish control and dominance. A good rhizome emerges through a politics of becoming, ultimately driven, if it works well, by the force of - love.

${ }^{5}$ As in the case of the panel at the annual meeting of the American Anthropological Association in Denver, November 18- 
invite their audiences to reflect on issues when they are, as Osterweil describes, "engaged in the selfreduction of supermarket prices and performed it as a rite to San Precario (Saint of Precarity)," or when other activists occupied "an abandoned space to create a laboratory for re-imagining the city, as with a temporary squat in the center of Bologna, 2004" (ibid: 607). This theoretical work does not derive from abstract decontextualized reasoning, but is the product of political practices and struggles. Escobar (2012) refers, for example, to the concept of Zapatismo as a political strategy that emerged in the political struggles of that movement in Chiapas, Mexico.

Another distinctive feature of much activism is the diverse composition of its membership. The Zapatista movement, for example, involves indigenous actors as much as metropolitan intellectuals, students and concerned citizens. In addition, the free store, the rent-for-free store, and the Repair Café where Ulrich is engaged in Germany are all run by a diversity of actors with various backgrounds and professions including freelance environmental teachers, accountants, civil service employees, professors, students, and many others. In the UK, to take another example, low impact housing and agro-ecological initiatives involve a diversity of actors and knowledges as well (cf. Chatterton and Pickerill 2010).

In view of the complexity and diversity of actors and knowledges involved in degrowth, it becomes clear that knowledge construction is a process marked by uncertainties and ongoing negotiations. Alternatives to modernity are always in the making and in an open process of experimentation as to what a good life is and how it can be realized in practice.

\section{Activist research - some strategies}

The ontological politics of science, the need for deconstruction and new imaginaries, and the particular character of socio-ecological movements lead us to rethink our role as researchers in terms of activist research. We are still engaged in doing and writing ethnography, recognizing the diversity of perspectives and the complexity of our projects. The role of ethnography, then, is to make visible and articulate particular ways of thinking, practices and social experiences that in turn continue to raise questions about our concepts. In so doing, we also engage ourselves and thus co-construct realities, as the researcher's voice is just one among many others. Accordingly, activist research implies "a decentralized notion of expertise and the multiplication of authorized voices" (Casas-Cortés et al. 2013: 202). It seeks to shift the process of research towards a more democratic and dialogic process of knowledge construction (cf. Cattaneo et al. 2012; Miller 2013).

This does not mean, however, that activist research entails simply adhering to the ideas of actors and movements. It rather means being involved in negotiations where we might also disconfirm, resist, critique and revise concepts and knowledge-including those of our interlocutors. This also implies, of course, that scientific knowledge and our views are subjected to critique and negotiation like any other actor's perspective. The deconstruction of conceptual frameworks is a crucial tool for activist research.

\section{Decentering the modern ontology}

Deconstruction is important as a pre-condition for activist research and as a strategy employed in collaborative fieldwork itself. To achieve socio-ecological transformation towards a degrowth society, it is imperative to overcome and decenter the growth-imaginary and to build a new imaginary with fresh images, concepts and narratives. ${ }^{6}$ But where do we get them or how do we construct them? Serge Latouche, for

22, 2015, which resulted in this Special Section on 'Culture, Power, Degrowth.'

${ }^{6}$ Degrowth is not, of course, a unified theory but a framework fed by a variety of streams of thought. "Degrowth is placed at the junction of several of such sources or streams of thought which cross each other without being in competition" (Bayon et al. 2010; in Demaria et al. 2013: 196). Some are ecology, critiques of development, praise for anti-utilitarianism, the meaning of life and wellbeing, bioeconomics, justice and democracy. 
example, has used anthropological texts as a source for a new imaginary. ${ }^{7}$ He suggests overcoming the western modern imaginary through "grasp(ing) the possibility of human life outside the confines of modernity" (1993: 187). The hope here is to work out features of possible societies through an understanding of non-capitalist societies (such as the Tanna and Kwakiutl, and those in Melanesia and Africa) and of informal economies in Africa as described by anthropologists (Latouche 1993: chapter 5).

However, drawing on ethnohistorical texts in the way it is proposed here implies certain dangers. Concepts such as the "gift" (Mauss 2002) or the "affluent society" (Sahlins 2004) can reinforce dualisms and appear as naturalized and essentialized features of non-capitalist sociopolitical organization. In his book, In the wake of the affluent society, Latouche (1993), for example, offers a critique of the concept of modern affluence and refers to "primitive affluence" (Sahlins 2004). He writes: "In the previous societies, wealth was considered a gift left behind by the dead and had meaning in its material or accumulative form only as a proof of recognition by the living of their debt to the dead" (Latouche 1993: 205). Unfortunately, we do not learn which so-called previous societies he is describing or in what socio-cultural contexts the described values had been developing. And, what is most important in our view, we do not know what these previous societies were thinking about their own so-called affluence. What if they desired increased consumption? While using selected ethno-historical references, we risk romanticizing, generalizing, and essentializing noncapitalist societies in a way that lacks historical and emic perspectives.

We sense similar dangers in the anti-utilitarian reference to the gift concept as a total social fact. ${ }^{8}$ Romano, for example, has claimed that the anti-utilitarian movement in its political variant maintains that "the democratic ideal can be revitalized only by doing away with any aims of interests, especially egoistic, from the collective discussion" (Romano 2015: 23). Anti-utilitarianism inspires degrowth activists in the search for alternative forms of economy. However, we should not forget that through these structural representations we have no insight into the local or emic interpretation of this supposedly total social phenomenon, and we cannot really say that self-interest is absent in the ethnographic gift economy. In fact, Mauss himself cautioned us against one-sided generalizations of economic systems. His anthropology was explicitly political in his critique of economic individualism and the paradigm of classical economics (individual choice, maximization of profit, etc.), but he was not recommending its direct antithesis. He was pointing at the complexity of coexisting human values such as freedom and duty, self-interest and care of others, etc. (Hann and Hart 2011: 48-53). Mauss' main conclusion was that the endeavor of creating a free market was equally impossible as its opposition - a system based on the principle of gift and reciprocity.

Susana Narotzky (2012) also warns against a reification of these 'other' economic relations that tends to endow them with a positive moral aura that refers to the primitive or primordial slot where they have been positioned before the fall into capitalism. Rather than reifying concepts such as the gift, we should see arguments on the gift or affluence in their historical context of the debate, for example, between substantivist and formalist anthropologists, but also in their relation to the mainstream economic theory that was building its hegemony in its day. At the same time, we need to pay close attention to emic perspectives and their complexity constructed in a variety of indigenous discourses and political practices.

The alternative economic practices of the neo-rural communities in Catalonia (Spain) Agata works with, for example, are based on a broad spectrum of economic principles ranging from autarchy to dependence on the external market, none of which can be described with reference to the paradigm of classical economics (individual choice, maximization of profit, utilitarianism, etc.). Yet, they do not correspond either with the principles offered by anthropological critiques of modernity and capitalism, which

\footnotetext{
${ }^{7}$ In our understanding of the term "imaginary" we follow Latouche who, in turn, follows Cornelius Castoriadis. The later, referring to the "Western world" defines "imaginary" as "psychosocial structure of people," "their attitude toward life." In this sense, both authors argue that any social change must be parallel to the deconstruction of previous imaginary and the construction of the new one (Latouche 2015: 147).

${ }^{8}$ Anti-utilitarianism "is a school of thought that critiques the hegemony of the epistemological postulate of economics" (Romano 2015: 21).
} 
focus on concepts of the gift, altruism, and affluence. Instead, in working with these neo-rural activists, we see that the actual principles at work deconstruct the dualisms of modern ontologies (gift/profit; needs/affluence; self-interest/altruism, etc.), allowing a conceptual space for new and more complex concepts.

Degrowth frameworks of thought do increasingly take these features into account. Eduardo Gudynas (2015), for instance, offers a complex analysis of Buen Vivir. His reflections may be a disincentive for romanticizing the movement, as he shows different uses of the label of Buen Vivir, its sociopolitical contexts and its diverse interpretations (2015: 201-202). Gudynas suggests: "Although extremely popular, both inside and outside Bolivia, there is strong evidence that suma qamaña [which means "living well" in the aymara language] is not found in the everyday life of aymara rural communities, but that the terms were a recent creation by the aymara sociologist Simón Yampara" (2011: 444). Moreover, as our own experience from Bolivia suggests, the idea of suma qamaña has been used by the government to legitimate extractivist and imperial politics by no means in favor of many indigenous people. This observation does not make Buen Vivir less important, but it demonstrates that it would not be helpful to simply identify it with a kind of indigenous ancient philosophy that has always been opposed to development or growth - since it may be a risky generalization and essentialize the idea relegating it to a de-contextualized traditional way of thinking.

Moreover, as ethnographic analyses show (Gezon 2017, Hummel 2005a, 2005b; Zárate 1991, 1994), local interpretations of the present and the past emerge in unique political contexts and should be analyzed as such. Developing the analysis of the concept of Buen Vivir that Gudynas offers can inspire degrowth theories and practices without relying on essentialist notions of indigeneity. Degrowth discourses, then, can clearly benefit from taking the complexity of socio-cultural phenomena into account.

Overcoming the modern conceptual framework, then, would not mean substituting one naturalized image (scarcity) with its opposite but equally naturalized concept (affluence). Instead, as Escobar (2008, 2012) suggests, we need to go beyond this ontology to study the ways alternatives like Buen Vivir, for example, are not only politically constructed in history but also are "relational ontologies" in that they "eschew the divisions between nature and culture, between individual and community and between us and them that are central to the modern ontology" (Escobar 2012: xviii). Deconstructing these dualisms, then, appears as a precondition for understanding Buen Vivir as a set of alternative discourses which do not oppose capitalism or growth, but that decenter it from the definition of our reality. Such a deconstruction of the modern imaginary, then, would open the way to learn to see the world as a pluriverse full of different discourses of transition and discourses all related to modernity, development and capitalism.

\section{Translation, imagination}

Another strategy is what Casas-Cortés et al. (2013) call translation. Translation is a way of putting something that is being said or done into another form, means of expression, or code: to render something more comprehensible to others or to enrich or unfold meanings. Thus translation is putting the "knowledge practices of the movements we are working with ... in relation to other sources, and at times putting them into other words" (Casas-Cortés et al.: 2013: 222). It can refer to the production of texts, websites, statements, manifestos, etc. It might also involve the production of a meta-discourse: defining freedom, political theory, the political, a good life, a community, what it means to be human, what a social movement is, etc.

Ulrich's research with an urban Transition Town initiative in Heidelberg (Germany) serves as an example of the work of translation. The movement: 
... began in Totnes in September 2006. Responding to the recognition of the need for a radically different way of life following the depletion of oil supplies and the requirement to reduce the carbon dioxide emissions that are causing climate change, communities are called upon to raise awareness, equip themselves with skills and knowledge and move together towards a lowenergy lifestyle. (Scott Cato and Hillier 2010: 874)

To date, more than one thousand communities across the world have been officially registered as Transition Towns. (See http://www.transitionnetwork.org). During the period of fieldwork in Heidelberg (from June 2014 to March 2016), this group comprised twenty-five active members ranging in age from eighteen to sixty-five, with a heterogeneous educational and professional background. Like other Transition Town groups, it aimed at bringing about a transition towards more sustainable and resilient ways of consumption, production, housing etc. Accordingly, the initiative was establishing socio-ecological projects such as a "repair café," a rent-for-free-store, and a gift-shop where people get things for free. These projects demanded a lot of volunteer work from each individual: for the free-for-rent-store, for example, two or three members worked to find a building, two others arranged the interior of the store, one person programmed the computer software, and so forth. In addition, the project required (at least) weekly meetings to distribute and organize the tasks. Nevertheless, all actors were proud of their particular contributions as unique individuals and gradually realized that this heterogeneity made a "good community" possible.

With time, the group gradually acknowledged the need for these heterogeneous individuals to deliberately and discursively engage in talks, meetings, or story-telling. The experience of connecting with one another through music, dance and having a "good time" with one another also emerged as very important. These were the conditions, then, for creating a good community - a social organism that can be understood as a rhizome.

However, most members of the Transition Town initiative were convinced that to experience themselves as a good community required additional processes. Through workshops, books and popular notions, some developed the idea that a community is created through communal experiences of being rooted in and connected to a "deeper" reality, to the effect that individuality, difference and heterogeneity give way to sameness and the experience of being one (with one another, with nature, the cosmos, etc.). Therefore, members were looking for and organizing events where they could emotionally experience what they saw as sameness, or a kind of "rootedness" and "unity," in order to "inwardly" (as people expressed it) experience community and transform their consciousness to "really" belong to it. That was explicitly called the "inner transition," and valued as the only way of really experiencing and thus building up the community. In the end, this vision posed a serious threat to the political work of establishing sustainable and alternative institutions in the town, because it increasingly led to a significant withdrawal from engagement in the projects and, on the other hand, to an increasing focus on and participation in events of inner transition.

In other words, to keep Transition Town Heidelberg working as a political group, the members needed a model of community that would allow actors to overcome the conceptual dualism between community and individual, thinking and experiencing, or thought and action, and to rethink their group in terms of a community that is built up and kept alive through the (also discursive) cooperation and co-engagement of heterogeneous individuals. We discovered such a model - the rhizome - in the writings of Deleuze and Guattari (1987). Subsequently, the rhizome became the topic of some of Ulrich's courses in anthropology at the university, and students worked (and also lived) through the dynamic of this concept. This experience made Ulrich (and the students) increasingly aware of the significance of the rhizome concept for selforganized initiatives. Later on, Agata and Ulrich visited the Degrowth project of Can Masdeu (in Barcelona) and found that there as well people understood the project explicitly as a rhizome. Back in Heidelberg, Ulrich reported on this experience and introduced the concept to the Transition Town group. This helped to create a new and more workable self-understanding of the initiative as an anti-hierarchical, self-organized, ethical social organism involved in processes of connecting, openings and closure, de-territorialization and re- 
territorialization. Translation, then, enables researchers to co-transform and co-construct the realities we are working on in different ways (cf. also the examples in Casas-Cortés et al. 2013).

\section{Weaving}

Activist research also means actively creating social relations or what Casas-Cortés et al. (2013) call "weaving." Translation not only generates understandings and knowledges, but also relations between a diverse set of actors and concerned people. As demonstrated in examples addressed in Casas-Cortés (2009), writing or co-writing texts, building websites for and with people, giving talks, telling stories, writing a blog for others to comment on are all activities that create relations across actors and networks, academia and everyday life, anthropologists and networks, etc. - but also among activists of the same initiative or within one movement. Agata is involved in an international degrowth network connected through an internet platform which provides a flexible framework for setting up collaboration and media spaces for communities and networks. The platform is used to discuss, write, share media, work collaboratively, and publish the results of actions to all members and serves as a resource of knowledge (Co-munity.net 2016). From time to time people from the network mobilize to conduct a joint project: conferences, summer schools, educational activities, to write papers, etc. Each time, different people from the same network are involved in actions and bring in their heterogeneous experiences. This virtual community can be conceptualized as a rhizome and functions as a tool for an activist weaving.

Between 2011 and 2015, the network has generated a specific community of knowledge exchange. Activists and researchers (often the same person with two roles) have been gathering every month or two in different places in Europe in some kind of degrowth initiative. The practical work and brainstorming workshops have been occasions for exchanging skills, experiences and knowledge on different subjects, for observing the hosting initiative as well as for creating spaces for the development of new joint knowledge. The exercises designed for the meetings had a purpose not only of exchanging experience and knowledge but also of elaborating solutions to existing problems - via new knowledge that was a result of the encounter. Methods used during the project, together with descriptions of the experience of the encounters, are available on co-munity.net. A printed and on-line anthology has been created containing chapters portraying each meeting contents (agreoecology and agriculture, work in degrowth society, community building and public policies), learning methodology and degrowth theory.

The exchange of knowledge within the network has incited the foundation of a degrowth discussion group in Warsaw and, above all, has helped to inspire the creation of the first community supported agriculture group in Poland. The discussion group gathered activists and scholars interested in deepening and in sharing degrowth knowledge and applying it to local realities. The community-supported agriculture group was partially linked to the discussion group. When Agata and another activist from Poland attended one of the first co-munity.net meetings in 2011 there was a presentation of experiences from the recently established CSA in Fribourg - GartenCoop. It turned out to be a great inspiration for the Polish participants. Back in our home city, Warsaw, we met with other people interested in founding the first CSA in Poland, and that is how the CSA Świerże Panki was born. ${ }^{9}$ The process of development of the Warsaw CSA was documented by a researcher and member of the CSA, Julia Olszewska, and later shared on researcher and activist forums. The weaving together did not stop on the local level. It has now expanded in the form of a comparative description of CSAs in Europe through the research within URGENCI - The International Network for Community Supported Agriculture with results soon to be published (Sylla, Olszewska, Świąder, Szewrański and Gonda-Soroczyńska 2017). ${ }^{10}$ From the beginning, it was supporting the process of building alternatives and was putting knowledge practices of the group of activists into other words: description, analysis, comparison.

\footnotetext{
${ }^{9}$ http://www.rws.waw.pl

${ }^{10}$ http://urgenci.net/the-csa-research-group
} 
In such processes, the particular expertise of anthropology can make a vital difference. Many anthropologists are concerned with knowledge about non-hierarchical or even egalitarian organization knowledge that the transformation initiatives urgently need. ${ }^{11}$ In the city of Heidelberg, for example, a governmental institution concerned with the promotion of fair trade and just sustainable relations (called the "one world house") tried to extend its work. It started to promote a network of sustainable alternative projects in the city. This institution, however, is organized in hierarchical and bureaucratic terms which ran counter to the variously non-hierarchical, self-organized and autonomous modes of grassroots politics. Grassroots projects refused to engage what they perceived as politics from above, citing, among other reasons, the way meetings were timed and organized, and the fact that decisions were supposed to be made not by consensus but by majority votes. Tensions that arose between the head of the institution and grassroots activists threatened the network. Nobody, however, articulated a coherent understanding of why that happened and, most importantly, what to do next.

Again, the notion of rhizome was key. Paul (an advanced student and activist) applied his expertise of social organization, and Ulrich could draw on his long term field work with non-hierarchical, egalitarian community organization in India. Accordingly, both tried to analyze the situation with reference to ideals of non-hierarchical self-organization of heterogeneous actors that the rhizome concept articulates. Ulrich and Paul collaboratively worked out some basic principles for the network (e.g. transparency, self-organization, consensus-based decisionmaking, non-hierarchical organization, an ethical politics, and transformation towards qualitatively "good" ways of living). ${ }^{12}$ They then introduced these principles to the network and, after several discussions, they were accepted. Activist research, then, had translated the concept of the rhizome into the code and practices of the network and contributed to the weaving of other and new social relations among the members.

\section{Conclusion}

In this article we have pointed to the ontological politics of knowledge and science in which research on degrowth, the movement, and its projects/initiatives are involved: a politics of practices through which reality is constructed and performed by and through many actors and practices, including researchers and scientific methods. Moreover, we proposed alternative ways to make use of the ontological politics of science and suggested that anthropology is helpful here in various ways. First, it can help to decenter the modern ontology on which even degrowth conceptualizations sometimes rest. Second, this method offers ways to empirically study alternatives to modernity, including degrowth projects themselves.

Drawing on recent reflections on activist research, we have outlined some of the tools that a method of anthropological activist research might include. In addition to the valuable tools of documentation and interpretation, the researcher can also "translate" meanings, texts, and voices. She can weave relationships between and within the diversity of actors and knowledges constituting the movements and projects. Anthropologists can also bring into diverse conversations their rich knowledge of non-capitalist and nonmodern ways of life, especially ethical ones. They also contribute the experiences they have had with other ways of living. Activist research is thus a method for deliberately fostering and bringing about good socioecological (and degrowing) ways of living - in practice!

Of course, we do not claim to have drawn an exhaustive picture here. Rather, the set of tools for activist research and the contributions of anthropology to the making of alternatives within a degrowth framework that we have presented are, to our mind, a first step: the work of anthropology for degrowth and other socio-ecological movements, it seems, has just begun.

\footnotetext{
${ }^{11}$ See also Casas-Cortés et al. (2013) on this point.

${ }^{12}$ For this "ethical politics of becoming," see footnote 11. For other anthropological perspectives see Demmer (2016).
} 


\section{References}

Bayon, D., F. Flipo and F. Schneider. 2010. La décroissance. 10 questions pour comprendre et en débattre. Paris: La Découverte.

Blaser, M. 2013. Ontological conflicts and the stories of people in spite of Europe: toward a conversation on political ontology. Current Anthropology 54(5): 547-568.

Casas-Cortés, M.I. 2009. Social movements as sites of knowledge production: precarious work, the fate of care and activist research in a globalizing Spain. PhD Dissertation. Chapel Hill: University of North Carolina. Academia

Casas-Cortés, M.I., M. Osterweil and D. Powell. 2013. Transformations in engaged ethnography: knowledge, networks, and social movements. In J.S. Juris and A. Khasnabish (eds.). Insurgent encounters. transnational activism, ethnography, and the political. Durham, N.C.: Duke University Press. Pp. 199-228. Researchgate

Cattaneo, C. 2006. Investigating neorurals and squatters' lifestyles: personal and epistemological insights on participant observation and on the logic of ethnographic investigation. Athenea Digital 10: 16-40.

Cattaneo, C., G. D'Alisa, G. Kallis, and C. Zografos. 2012. Degrowth futures and democracy. Futures 44(6): 515-523.

Chatterton, P. and J. Pickerill. 2010. Everyday activism and transitions towards post-capitalist worlds. Transactions of the Institute of British Geographers NS 35: 475-490.

Co-munity.net. 2016. https://co-munity.net [accessed January 2016].

D'Alisa, G., F. Demaria and G. Kallis (eds.). 2015. Degrowth: a vocabulary for a new era. London: Routledge.

D'Alisa, G. and G. Kallis. 2015. Post-normal science. In D'Alisa, G., F. Demaria and G. Kallis (eds.). 2015. Degrowth: a vocabulary for a new era. London: Routledge.

Deleuze, G. and F. Guattari. 1987. One thousand plateaus. Minneapolis: University of Minnesota Press.

Demaria, F., F. Schneider, F. Sekulove and J. Martinez-Alier. 2013. What is de-growth? From an activist slogan to a social movement. Environmental Values 22: 191-215.

Demmer, U. 2016. Towards another reason. identity politics and ethical worlds. Delhi: Oxford University Press.

Escobar, A. 2008. Territories of difference: place, movement, life, redes. Durham: Duke University Press.

Escobar, A. 2009. Other worlds are (already) possible: self organization, complexity, and post-capitalist cultures. In J. Sen and P. Waterman (eds.). The world social forum: challenging empires. Montreal: Black Rose Books.

Escobar, A. 2012[1995]. New preface. In A. Escobar Encountering development: the making and unmaking of the third world. Princeton: Princeton University Press.

Funtowicz, S. and J.R. Ravetz. 1993. Science for the post-normal age. Futures 25(7): 739-755.

Gezon, L.L. 2017. Beyond (anti)utilitarianism: khat and alternatives to growth in northern Madagascar. Journal of Political Ecology 24: 582-594.

Graeber, D. 2009. Direct action: an ethnography. Oakland: AK Press.

Gudynas, E. 2011. Buen vivir: today's tomorrow. Development 54(4): 441-447.

Gudynas, E. 2015. Buen vivir. In D'Alisa, G., F. Demaria and G. Kallis (eds.). 2015. Degrowth: $a$ vocabulary for a new era. London: Routledge.

Hann, C. and K. Hart. 2011. Economic anthropology. history, ethnography, critique. Cambridge, Malden: Polity Press. 
Hernández, Z. and J. Eduardo. 1991. Notas para la interpretación del movimiento étnico en Michoacán. In Muro V.G. and M. Canto Chac (eds.). El estudio de los movimientos sociales: teoría y método. Zamora/México D.F.: El Colegio de Michoacán, UAM.

Hernández, Z. and J. Eduardo. 1994. La fiesta del año nuevo Purhépecha como ritual político: notas en torno al discurso de los profesionales indígenas purhépechas. In Roth Seneff A. and J. Lameiras (eds.) El verbo oficial: política moderna en dos campos periféricos del estado mexicano. Zamora: El Colegio de Michoacán, ITESO.

Hummel, A. 2005a. El contexto social de la fiesta étnica de Año Nuevo Purhépecha - reflexiones teóricas. Estudios Latinoamericanos 25: 33-49.

Hummel, A. 2005b. Obchody fiesty Año Nuevo Purhépecha w kontekście rewitalizacji etnicznej. Afryka, Azja, Ameryka Lacińska 82: 47-60.

Latouche, S. 1993. In the wake of the affluent society. an exploration of postdevelopment. London: Zed Books.

Latouche, S. 2015. Decolonization of imaginary. In D'Alisa, G., F. Demaria and G. Kallis (eds.). 2015. Degrowth: a vocabulary for a new era. London: Routledge.

Law, J. and J. Urry. 2004. Enacting the social. Economy and Society 33(3): 390-410.

Luetchford, P. and J. Pratt (eds). 2014. Food for change: the politics and values of social movements. London. Pluto Press.

Martinez-Alier, J., I. Anguelovski, P. Bond, D. Del Bene, F. Demaria, J.F. Gerber, L. Greyl, W. Haas, H. Healy, V. Marín-Burgos, G. Ojo, M. Porto, L. Rijnhout, B. Rodríguez-Labajos, J. Spangenberg, L. Temper, R. Warlenius and I. Yánez. 2014. Between activism and science: grassroots concepts for sustainability coined by Environmental Justice Organizations. Journal of Political Ecology 21: 19-60.

Mauss, M. 2002. The gift: the form and reason for exchange in archaic societies. London and New York: Routledge.

Miller, Th. 2013. Constructing sustainability science: merging perspectives and research trajectories. Sustainability Sciences 8: 279-293.

Narotzky, S. 2012. Alternatives to expanded accumulation and the anthropological imagination: turning necessity into a challenge to capitalism? In P. Gardiner Barber, B. Leach and W. Lem (eds.). Confronting capital critique and engagement in anthropology. London: Routledge.

Osterweil, M. 2013. Rethinking public anthropology through epistemic politics and theoretical practice. Cultural Anthropology 28 (4): 598-620. Scribd

Rocheleau, D.E. 2007. Political ecology in the key of policy: from chains of explanation to webs of relation. Geoforum 39: 716-727. Academia

Romano, O. 2015. Anti-utilitarianism. In D'Alisa, G., F. Demaria and G. Kallis (eds.). 2015. Degrowth: $a$ vocabulary for a new era. London: Routledge.

Sahlins, M. 2004. The original affluent society. In M. Sahlins. Stone age economics. London: Routledge.

Santos B. 2007. The rise of the global left: the world social forum and beyond. London: Zed Books.

Scott Cato, M. and J. Hillier. 2010. How could we study climate-related social innovation? Applying Deleuzean philosophy to Transition Towns. Environmental Politics 19(6): 869-887.

Slocum, R. and K.V. Cadieux. 2015. Notes on the practice of food justice in the U.S.: understanding and confronting trauma and inequity. Journal of Political Ecology 22: 27-52.

Sylla M., M. Olszewska, M. Świąder, S. Szewrański and E. Gonda-Soroczyńska. 2017. Status and prospects and the development of the community supported agriculture in Poland as an example of a short food supply chain. Journal of Agribusiness and Rural Development (in press). 
Williams, G. 2008. Struggles for an alternative globalization: an ethnography of counterpower in Southern France. Hampshire, Burlington: Ashgate. 